\title{
Ларингомалация при деца с вроден стридор
}

По материали на УНГ-клиника при УМБАЛ „Свети Георги“- Пловдив

\author{
Д. Николов, Н. Криворов, И. Йовчев \\ Клиника по оториноларингология, \\ Медицински университет - Пловдив
}

Настоящата публикация е част от научен проект ДО 02.349/29.12.2008 г. „Интегриран научно-изследователски центьр по детско здраве“, осъществяван с финансовата подкрепа на Фонд „Научни изследвания“ към МОН.

\section{Въведение}

Ларингомалацията е вродено състояние, при което тонусът на ендоларинкса е отслабен. Това от своя страна довежда до динамичен колапс на структурите на супраглотиса към кухината на ендоларинкса и обтурация на рима глотидис. Това води до поява на характерен стридор при инспириум (1, 2). Стридорът се засилва по време на хранене, като понякога се появява и регургитация и хълцане. Ларингомалацията е най-честата вродена аномалия на дихателните пьтища. Според различни автори тя се среща в $45-75 \%$ от всички случаи на конгенитален стридор $(3,4)$. Етиологията е неясна, като се подозира увреда на сензомоторната функция на ларинкса и нарушение на ларингеалния аддукторен рефлекс, отговорен за осъществяването на затварянето на рима глотидис и прегльщането (3, 4). В повечето случаи заболяването започва между 2-3 седмица от живота и отзвучава спонтанно до 24-я месец от живота (5). В 90\% от случаите заболяването отзвучава спонтанно. В тежки случаи, които се наблюдават изключително рядко, може да се достигне до тежка асфиксия, цианоза, cor pulmonale, продължителни апноични паузи, които могат да доведат и до смърт. В такива случаи авторите пропоръчват оперативно лечение (5), което се състои в трахеотомия по витални индикации и супраглотопластика с помощта на микроларингохирургична техника или СО-лазер. 


\section{Цел и задачи}

Основни цели:

- да опишем характерните ендоскопски находки при деца с ларингомалация, наблюдавани при нас за периода 2008-2010 г;;

- да определим средното време за естествена резолюция на заболяването по нашия материал;

- да изтькнем предимствата на фиброендоскопската ларингоскопия пред класическата директна ларингоскопя под обща инхалационна анестезия, каквато използвахме до 2008 г. за диагностика на децата с ларингеален стридор.

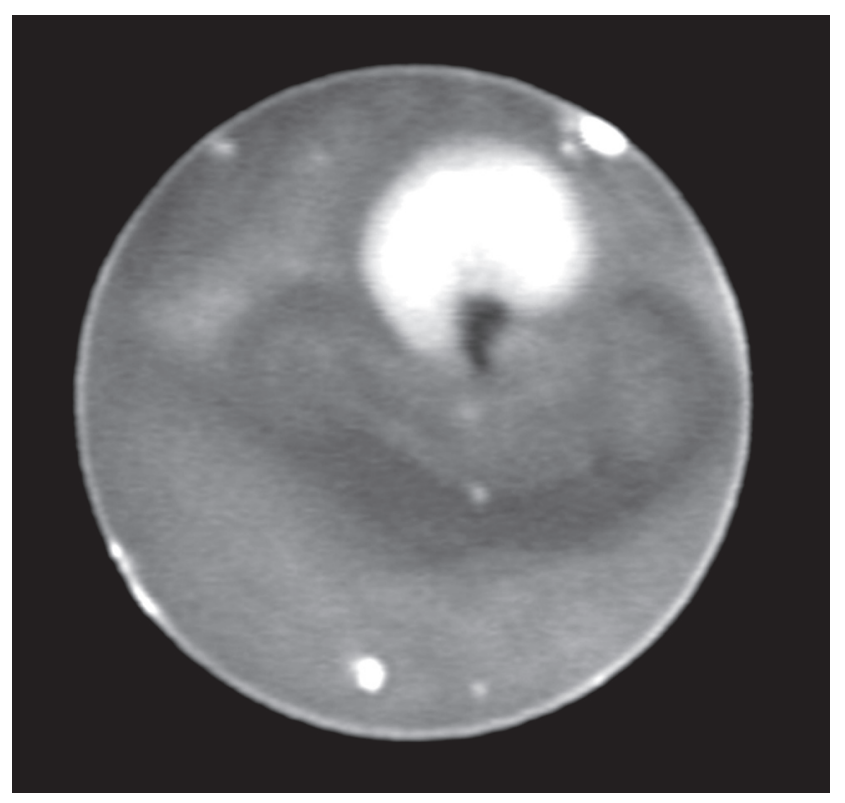

(Г. К. 3 м) фаза на експириум

На всички деца извършвахме фиброларингоскопия с горепосочения апарат. Ендоскопското изследване извършвахме без анестезия или с незначителна седация с 0.1 мг/кг мидазолам, използвахме за лубрикант 5\% лидокаинов гел, с който намазвахме върха на фибробронхоскопа. Апарата въвеждахме трансназално и започвахме визуализирането на ларинкса от епиглотиса, като отчитахме неговата форма, подвижността му по време на дишането. Визуализирахме състоянието и обема на ариепиглотичните гънки и тяхното движение при инспириум и експириум и степента на колабирането им към рима глотидис при инспириум. След това с директен контакт на върха на апарата върху интераритеноидното пространство стимулирахме ларингеалния аддукторен рефлекс и отчитахме дали след появата му се появява акт на гълтане

\section{Методи и материали}

На 24 деца на възраст от 10 дни до 3 месеца (средна възраст 45 дни) с картината на ларингеален инспираторен стридор, които бяха насочени от Клиниката по педиатрия, извършихме фиброларингоскопия с фибробронхоскоп Olympus Evis Exera II CV105 с външен диаметър 2.2 м, работен канал 1 мм адаптиван към видеосистемата на Olympus Evis Exera II, който дава високо качество и яснота на образа и осигурява прецизно възпроизвеждане на фините лигавични структури. Изображенията съхранявахме и записвахме на DVD носител за документация.

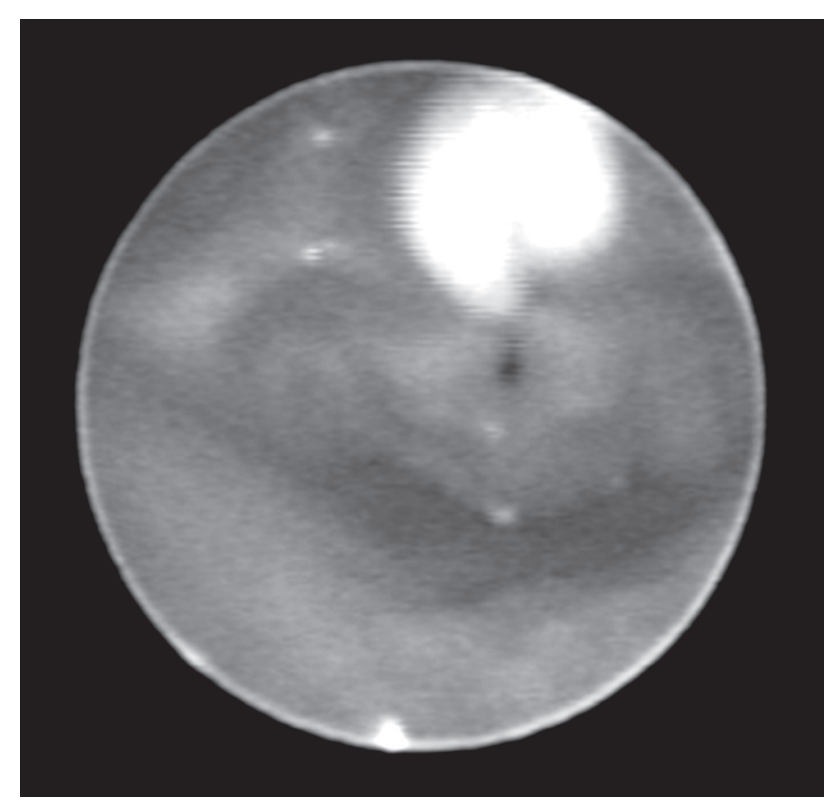

фаза на инспириум

като през работния канал инсуфлирахме 5 мл физиологичен серум. Ендоскопските находки записвахме на магнитен носител за последваща преценка, фотодокументация и архивиране. По време на изследването децата бяха мониторирани по отношение на основни витални показатели, също така и след ендоскопското изследване, а именно Р 02, Р СО2, ЕКГ, КГА. Преди ендоскопията бяха консултирани с педиатьр по отношение белодробния и сърдечния статус. Общото състояние оценявахме по общоприетата скала за заболяването, като ги разделяхме на такива с лека, средно тежка и тежка степен на стридор. С оглед изключването на други аномалии на трахео бронхиалното дърво, които могат да причинят стридор, завършвахме изследването с фибротрахеобронхоскопия, за да отхвьрлим конгенитални субхордални стенози, вродена трахеомалация 
или други бронхиални аномалии. Децата бяха изследвани контролно в Клиниката през 6 месеца по гореописания алгоритьм, за да отчетем естествения ход на заболяването.

\section{Резултати}

Съобразно ендоскопската находка наблюдавахме три вида различни ендоскопични картини:

- „класическа“ - характеризираща се с типичния омегаобразен епиглотис, като при 8 деца той имаше практически цилиндрична издължена форма;

- Силно наведен напред мек флексибилен епиглотис, който при инспириум застава върху рима глотидис и я обтурира или вибрира при вдишване и издишване. Тази картина се наблюдаваше при 4 от изследваните деца;

- Къси задебелени ариепиглотични гънки на вид хипертрофирали, чиято лигавица при инспириум колабира към кухината на ендоларинкса и го обтурира. Тази картина наблюдавахме при 12 деца.

По време на ендоскопиите всички основни витални показатели показваха нормални стойности. На 6-я месец от началото на заболяването децата бяха ендоскопирани отново по същия метод. При 4 от пациентите, на които стридорьт беше започнал в началото на третия месец от раждането, ендоскопската картина беше нормализирана, като все още се оставаше с впечатление за омегаобразна форма на епиглотиса, но без наличието на инспираторен колапс, т.е. естествената резолюция по отношение на стридора беше настьпила към 9-я месец от живота на детето.

При 9 от пациентите картината се нормализира след 12-я месец от живота.

При 5 от пациентите естествената резолюция настъпи след 18-я месец от живота.
Шест от наблюдаваните пациенти не се явиха на поредни контролни прегледи и нямаме информация за тяхното състояние.

В нашата серия от наблюдавани пациенти нямаше случай на дете с тежка степен на ларингомалация, която да налага оперативна интервенция.

\section{Обсъждане}

Всички от нашите пациенти достигнаха до естествена резолюция на заболяването си в порядъка на 12-24 месеца от появата на стридора.

\section{Изводи}

Ларингомалацията е особено заболяване, в основата на което стоят все още не съвсем изяснени механизми на нарушение на ларингеалния тонус, водещ до появата на динамичен колапс на меките тъкани на супраглотиса към кухината на ендоларинкса.

При леките и средно тежки случаи единственият лечебен фактор е времето, като симптомите на стридора отзвучават за около 12-24 месеца от появата му. Това се потвьрждава и от наблюдаваните от нас пациенти.

Златен стандарт в диагностиката се явява фиброларинготрахеобронхоскопията, която дава възможност за преценка на състоянието на ларинкса в динамика и дава възможност за преценка кои точно структури на супраглотиса колабират по време на вдишване. Желателно е процедурата да се извършва с детски фибробронхоскоп с дебелина 2-3 мм и трябва да завърши с фибробронхоскопия за изключване на други редки аномалии на трахеобронхиалното дърво.

\section{Литература:}

1. Baxter MR. Congenital laryngomalacia. Can J Anaesth 1994; 41: 332-339

2. Belmont JR, Grundfast K. Congenital laryngeal stridor (laryngomalacia): etiological factors and associated disorders. Ann Otol Rhinol Laryngol 1984; 93: 430-437

3. Apley J. The infant with stridor: a follow-up survey of 80 cases. Arch Dis Child 1953; 28: 423-435

4. Thompson DM. Abnormal sensorimotor integrative function of the larynx in congenital laryngomalacia: a new theory of etiology. Laryngoscope. 2007; 117(6): 1-33

5. Polonovski JM, Contencin P, Francois M, Viala P, Narcy P. Aryepiglottic fold excision for the treatment of severe laryngomalacia. Ann Otol Rhinol Laryngol. 1990 Aug; 99(8): 625-7 